\title{
FAKTOR YANG MEMPENGARUHI MAHASISWA MEMILIH PROGRAM STUDI MANAJEMEN PENDIDIKAN ISLAM (MPI) FAKULTAS TARBIYAH DAN KEGURUAN UIN ALAUDDIN MAKASSAR
}

\author{
HAMSIAH DJAFAR \\ Fakultas Tarbiyah dan Keguruan \\ Universitas Islam Negeri Alauddin Makassar
}

\begin{abstract}
:
The presence of management education in the world of education has attracted many people's attention to the world of education, as happened in the new academic year 2015 the number of applicants of students reaching the number of approximately 8000 an applicant candidate for new students in UIN ALAUDDIN Makassar as well as management enthusiasts the existing education at UIN Alauddin Makassar University experienced a significant increase of registrants especially in the Department of Management education. Although not all of the applicants can be admitted to the majors chosen by new students, this can not dampen the enthusiasm of new students to enter UIN Alauddin University's lecture in Makassar especially in the Department of Education Management. Thus attract the attention of authors to study about Factors Affecting Students Choosing Islamic Education Management Study Program at the Faculty of Tarbiyah and Teacher UIN Alauddin Makassar Academic Year 2015/216. The factors that encourage students to choose to enter the Department of Islamic Education Management are due to their own desires, family support (older siblings, parents) and the Department of Islamic Education Management has been accredited B, as well as the time faculty in high school / equivalent.
\end{abstract}

Keywords: Student, Islamic Education Management

\section{PENDAHULUAN}

\section{Latar Belakang Masalah}

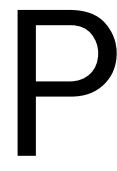

endidikan mempunyai tugas menyiapkan sumber daya manusia untuk pembangunan. Derap langkah pembangunan selalu diupayakan seirama dengan tuntutan zaman. Perkembangan zaman selalu memunculkan persoalan-persoalan barn yang tidak pernah terpikirk.an sebelumnya.

Dunia pendidikan saat ini sedang diguncang oleh berbagai perubahan yang sesuai dengan tuntutan dan kebutuhan masyarakat, serta dituntut menjawab permasalahan lokal dan perubahan global yang terjadi begitu pesat. Kesadaran akan tampilnya dunia pendidikan dalam memecahkan dan merespon berbagai tantangan yang timbul pada setiap zaman adalah suatu hal yang logis bahkan suatu keharusan. Hal yang demikian mengingat dunia pendidikan merupakan salah satu pranata yang terlibat langsung dalam mempersiapkan masa depan umat manusia. Kegagalan dunia pendidikan dalam menyiapkan masa depan umat manusia 
merupakan kegagalan bagi kehidupan bangsa (Nata, 2003:171). Terlebih lagi dalam Undang-Undang Republik Indonesia Nomor 20 tahun 2003 tentang sistem pendidikan nasional mengatakan bahwa wajib belajar merupakan tanggung jawab negara yang diselenggarakan oleh lembaga pendidikan pemerintah, daerah dan masyarakat. Olehnya itu pendidikan perlu diorganisasikan dalam sebuah wadah yang termenej dengan baik.

Namun menurut Mudyaiiardjo (2013) tidak dapat dipungkiri dalam pengembangan pendidikan terdapat berbagai masalah yaitu (1) masalah partisipasi pendidikan masalah ini berkenaan dengan rasio atau perbandingan antara masukan pendidikan atau jumlah penduduk yang tertampung di dalam satuan-satuan pendidikan, baik di sekolah maupun diluar sekolah, dengan jumlah penduduk yang secara potensial sudah, siap memasuki satuan-satuan pendidikan. Makin besar kesenjangan antara jumlah penduduk yang harusnya memperoleh pendidikan. Dengan demikian, masalah partisipasi pendidikan merupakan masalah kesempatan memperoleh pendidikan. Masalah ini sekurang-kurangnya berkenaan dengan masalah; (a) kondisi sosial ekonomi keluarga, (b) kondisi fisik dan mental calon peserta didik, (c) kondisi tempat pendidikan yang tersedia, (d) tingkat aspirasi masyarakat tentang peranan dan pentingnya pendidikan dalam nidup dan (e) daerah jangkauan sama pendidikan. Masalah yang (2) yaitu masalah efesiensi pendidikan masalah ini berkenaan dengan proses pengubahan atau transformasi masukan produk (input) menjadi produk (output). Dengan demikian berhubungan mutu transformasi administratif dan operasional dalam sistem pendidikan nasional. Salah satu menentukan mutu transformasi pendidikan adalah menghitung besar kecilnya penghamburan pendidikan atau educational wastage, dalam arti menghitung besar kecilnya jumlah murid/siswa/ mahasiswa/ warga belajar yang: (a) putus sekolah (drop out putus sekolah adalah sebelum menyelesaikan keseluruhan masa belajar yang telah ditetapkan oleh lembaga pendidikan yang bersangkutan, (b) pengulangan (repetition) pengulangan adalah murid/siswa/mahasiswa/ warga belajar yang sama tidak naik kelas atau naik jenjang.

Makin besar jumlah murid/siswa/mahasiswa/warga belajar yang putus sekolah atau mengulangi, menunjukkan alur proses penyelesaian belajar (student flow) makin tidak lancar atau tidak efisien. Masalah transformasi pendidikan berkenaan dengan masalah mutu ; (a) tenaga kependidikan terutama mutu tenaga mengajar yang sangat berhubungan dengan mutu kemampuan profesional dan fisik kepribadian, (b) peserta didik, yang sangat berhubungan erat dengan mutu kesiapan belajar, mutu kemampuan belajar, dan mutu mereka belajar, (c) kurikulum atau program belajar-mengajar yang menjadi acuan kegiatan belajar mengajar, (d) sarana dan prasarana pendidikan, yang tersedia yang digunakan dalam proses belajar mengajar dan proses administrasi pengelolaan pendidikan dan (e) suasana sosial budaya yang tersedia dalam lingkungan kerja.

Masalah yang (3) masalah efektifitas pendidikan masalah ini berkenaan 
dengan rasio antara hasil pendidikan (output) dengan tujuan pendidikan. Hal ini berkenaan dengan kesesuaian antara apa yang dapat dihasilkan dengan apa yang diharapkan, baik dalam hal kualitas maupun kuantitas. Makin besar kesesuaiannya makin efektiflah pendidikan. Masalah efektifitas pendidikan berkenaan dengan; (a) kesesuaian jumlah tamatan yang dapat dihasilkan dengan jumlah tamatan yang diharapkan atau yang seharusnya dapat dihasilkan dalam setiap satuan pendidikan, (b) kesesuaian mutu tamatan yang dapat dihasilkan

dengan mutu tamatan yang diharapkan dalam menguasai kemampuankemampuan kognitif, efektif dan psikomotor.

Serta masalah yang ke (4) masalah relevansi pendidikan masalah ini berkenaan dengan rasio antara tamatan yang dihasilkan pendidikan dengan tenaga kerja dan individu yang dibutuhkan dalam hidup masyarakat, baik secara kuantitatif maupun kualitatif. Dengan demikian, masalah relevansi pendidikan adalah masalah kesesuaian tamatan yang dihasilkan pendidikan dengan kebutuhan masyarakat, baik sebagai tenaga kerja maupun sebagai pribadi dan anggota masyarakat pada umumnya. Masalah relevansi pendidikan sedikit banyak berhubungan dengan; (a) ketersediaan lapangan kerja dalam masyarakat, (b) perkembangan dan perubahan yang cepat dalam jenis dan tugas-tugas pekerjaan. Jenis dan tugas-tugas tenaga pekerjaan dalam masyarakat tidak tetap, tapi berubah yang tidak jarang tidak dapat diikuti oleh lembaga pendidikan, terutama sekolah yang mempunyai kurikulum relatif tetap, (c) aspirasi dan tuntutan masyarakat yang terns meningkat dalam upaya mencapai mutu kehidupan, (d) mutu dan perolehan tamatan yang dihasilkan sekolah secara faktual tidak dapat memenuhi harapan dan kebutuhan dunia kerja. Mutu tamatan yang dibawah standar dan jumlah yang kurang atau berlebihan merupakan masalah inti relevansi pendidikan.

Penerapan manajemen pendidikan sebagai unsur utama dalam pelaksanaan suatu kegiatan kelembagaan dapat mengurangi atau setidaknya menghindari kesalahan-kesalahan dalam bertindak pada saat terjadinya proses atau usaha pencapaian tujuan yang sedang berlangsung (Yakub, 1994:17). Dalam aplikasinya yang lebih jauh, manajemen berusaha memberikan landasan gerak tertib, teratur dan terencana dalam suatu format program kerja yang rapi Format ini akan memberikan kemudahan-kemudahan dalam melaksanakan aktivitas pendidikan yang memperlancar tugas-tugas kearah pencapaian yang lebih optimal. Olehnya itu, dalam manajemen pendidikan terlibat fungsi-fungsi operasional yang harus dilaksanakan, yaitu: perencanaan, pengorganisasian, pengarahan, pengkoordinasian, pengkomunikasian, dan pengawasan (Ishak dan Suarga, 2009:14).

Berdasarkan hasil pengamatan sementara penulis melihat dengan Hadirnya pendidikan manajemen dalam dunia pendidikan telah banyak menarik perhatian masyarakat terhadap dunia pendidikan, seperti halnya yang terjadi pada tahun ajaran baru tahun 2015 jumlah pendaftar mahasiswa mencapai angka kurang lebih 
8000 an orang pendaftar calon mahasiswa bam di UIN ALAUDDIN Makassar demikian halnya dengan peminat manajemen pendidikan yang ada di Universitas UIN Alauddin Makassar mengalami kenaikan pendaftar yang begitu signifikan khususnya di jurusan Manajemen pendidikan. Meskipun tidak semua dari jumlah pendaftar dapat diterima di jurusan yang telah dipilih oleh calon mahasiswa barn hal ini tidak dapat menyurutkan semangat para peserta mahasiswa baru untuk masuk kuliah di Universitas UIN Alauddin Makassar khususnya pada Jurusan Manajemen Pendidikan.

Dengan demikian menarik perhatian penulis untuk mengkaji tentang Faktor Yang Mempengaruhi Mahasiswa Memilih Program studi Manajemen Pendidikan Islam pada Fakultas Tarbiyah dan Keguruan UIN Alauddin Makassar Tahun Akademik 2015/216.

\section{METODOLOGI PENULISAN Jenis Penulisan}

Menentukan jenis penulisan sebelum terjun ke lapangan adalah sangat penting. Sebab jenis penulisan merupakan payung yang akan digunakan sebagai dasar utama pelaksanaan riset. Oleh karenanya penentuan jenis penulisan didasarkan pada pilihan yang tepat karena akan berimplikasi pada keseluruhan riset. Dilihat dari jenisnya, penulisan ini adalah penulisan lapangan (field research), yang mana penulisan ini menarik beratkan pada hasil pengumpulan data dari informan yang telah ditentukan.

Penulisan lapangan (field research) adalah penulisan secara langsung terhadap objek yang diteliti, yaitu dari hasil wawancara atas informan terhadap

(1) Apa yang menjadi daya tarik manajemen pendidikan bagi mahasiswa baru?

(2) Apa alasan mahasiswa baru memilih kuliah di UIN Alauddin Makassar khususnya pada jurusan Manajemen Pendidikan? (3) Apa harapan yang ingin dicapai oleh mahasiswa baru sehingga memilih jurusan Manajemen Pendidikan? (4) Apa yang menjadi faktor pendorong dan penghambat mahasiswa baru untuk bisa mengambil jurusan Manajemen Pendidikan di Universitas UIN Alauddin Makassar? Dengan tujuan untuk mendapatkan data-data yang berkaitan dengan pembahasan penulisan ini.

Sedangkan sifat penelitian ini adalah penelitian deskriptif. Metode deskriptif adalah suatu metode dalam meneliti status sekelompok manusia, suatu objek, kondisi, sistem pemikiran, ataupun peristiwa pada masa sekarang. Tujuan dari penelitian deskriptif adalah untuk membuat deskripsi, gambaran atau lukisan secara sistematis, faktual dan akurat mengenai fakta, sifat serta hubungan antar fenomena yang diteliti. 


\section{Instrumen Penelitian}

Jenis penelitian yang dipilih adalah penelitian kualitatif yang menurut penulis memahami secara langsung dan mendalam terhadap fenomena yang ada di masyarakat, Dalam penelitian kualitatif, yang menjadi instrument penelitian adalah penulis itu sendiri. Seorang penulis haruslah memiliki kemampuan terhadap pemahaman metode penulisan kualitatif, penguasaan wawasan terhadap bidang yang diteliti, kesiapan peneliti untuk obyek penulisan.

Penulis sebagai instrument penelitian berfungsi menetapkan fokus penelitian, memilih informan sebagai sumber data, melakukan pengumpulan data dalam hal ini penulis memahami teknik penelitian data sehingga bisa memberikan kesimpulan atas temuannya.

Dengan demikian, penulis selain harus memiliki pengetahuan tentang metode penelitian kualitatif, juga harus disertai dengan alat ukur yang membantu dalam proses penelitian. Adapun alat yang bisa membantu, bisa berupa buku catatan dan alat tubs yang bisa memuat segala hasil wawancara dari responden atau para informan, dengan mencatat segala percakapan dengan sumber data.

\section{Teknik Pengumpulan Data}

Dalam penelitian teknik pengumpulan data merupakan hal yang utama karena untuk mendapatkan data yang akurat selain itu tanpa teknik pengumpulan data penulis tidak akan mendapatkan data yang memenuhi standar data yang diharapkan. Maka dari itu penulis melakukan penelitian dengan menggunakan metode pengumpulan data primer dan sekunder.

\section{Teknik Analisis Data}

Analisis data merupakan proses mencari dan menyusun secara sistematis data yang diperoleh dari hasil wawancara atau bahan-bahan lain Untuk menghindari banyaknya kesalahan dan mempermudah pemahaman Maka dalam teknik analisis data, penulis disini menggunakan:

1) Edit (Editing)

Mengedit yaitu mengoreksi kesalahan-kesalahan yang ditemui. Sebelum data diolah, data tersebut perlu di edit lebih dahulu. Dengan perkataan lain, data atau keterangan yang telah dikumpulkan, daftar pertanyaan ataupun pada nasi! wawancara perlu dibaca sekali lagi dan diperbaiki. Tujuan dari pada editing adalah untuk mengurangi kesalahan atau kekurangan yang ada di dalam daftar pertanyaan yang sudah diselesaikan sampai sejauh mungkin.

2) Klasifikasi (Classifying)

Klasifikasi adalah mereduksi data yang ada dengan cara menyusun dan mengklasifikasikan data yang diperoleh dalam pola tertentu atau permasalahan tertentu untuk mempermudah pembahasannya. Hal ini penulis tunjukkan dengan mengklasifikasikan berbagai jawaban dari responden dan para 
informan. Sehingga menjadikan pembacaan penelitian lebih mudah karena telah dikelompokkan dalam berbagai kategori. Dengan mereduksi data berarti memilih yang pokok atau memfokuskan pada hal-hal yang penting.

3) Verifikasi (verifying)

Verifikasi yaitu langkah dan kegiatan yang dilakukan pada penelitian ini untuk memperoleh data dan informasi dari lapangan harus diteliti kembali agar validitasnya dapat diakui oleh pembaca. Misalkan melakukan konfirmasi pada sumber data lain. Baik sekunder maupun sumber primer. Seperti konfirmasi pada pihak lain yang dapat memberikan data seperti tokoh masyarakat. Karena informasi tersebut dapat membantu memberikan keterangan yang objektif.

4) Analisis (Analyzing)

Analisis adalah mengelompokkan, membuat suatu urutan, serta meningkatkan data sehingga mudah untuk dibaca. Tujuan analisis di dalam penelitian ini adalah membatasi penemuan-penemuan hingga menjadi data yang teratur, serta tersusun. Adapun analisis data yang digunakan dalam penelitian ini adalah deskriptif kualitatif. Deskriptif kualitatif merupakan metode analisis data dengan cara menggambarkan keadaan kemudian dipisahk.an menurut kategori untuk memperoleh kesimpulan.

Dengan demikian, dalam penelitian ini data yang diperoleh melalui wawancara, dokumentasi, dipisah-pisahkan dan dikategorikan sesuai dengan rumusan masalah. Dengan demikian, Metode analisis ini digunakan untuk menganalisis data dari hasil wawancara, observasi, dan dokumentasi yang diperoleh penulis di lapangan.

5) Kesimpulan (Conducing)

Setelah semua tahap-tahap tersebut dilakukan maka langkah terakhir yaitu, pengambilan kesimpulan dari penelitian berdasarkan data yang ada untuk mendapatkan suatu jawaban. Sedangkan Analisa data adalah proses penyederhanaan data kedalam bentuk yang lebih mudah dibaca. Pada tahap ini peneliti membuat kesimpulan atau poin-poin penting yang kemudian menghasilkan gambaran secara ringkas, jelas dan mudah dipahami tentang realita yang terjadi di lapangan.

\section{PEMBAHASAN}

\section{Daya Tarik Jurusan Manajemen Pendidikan Islam Bagi Mahasiswa Baru}

Pada tahun akademik 2015/2016 UIN Alauddin Makassar menerima mahasiswa baru dari berbagai jurusan dan Prodi. Salah satu jurusan yang dipilih oleh mahasiswa baru adalah jurusan Manajemen Pendidikan Islam. Pemeliharaan jurusan tersebut memiliki daya tarik tersendiri sehingga diminati oleh mahasiswa baru sebagai satu pilihan.

Untuk lebih jelasnya peneliti mewawancarai informan untuk mengetahui apa daya tarik mahasiswa baru, sehingga memilih jurusan Manajemen Pendidikan Islam. 
Menurut Musdalipa:

Dari awal saya mendaftar di UIN Alauddin Makassar sebenarnya saya ingin mengambil Jurusan PAI, akan tetapi pada saat saya melihat akreditasi dari PAI menurun, maka saya beralih pada Manajemen Pendidikan Islam karena akreditasinya adalah $\mathrm{B}$.

Menurut Nur Hatika

Karena Manajemen Pendidikan Islam adalah Manajemen Pendidikan Islam dimana membahas tentang Manajemen dan pendidikan. Jujur saya memilih Manajemen umum (ekonomi) tapi ketika saya membuka pengumuman itu temyata saya lulus di Manajemen Pendidikan Islam. Tapi itu tidak masalah bagiku karena Manajemen Pendidikan Islam termasuk juga Manajemen dan pendidikan.

Menurut Ince Rika Rahim:

Saya bersungguh-sungguh masuk di jurusan MPI ini karena merupakan kriteria saya, karena saya bercita-cita masuk bekerja di bank tapi yang saya khawatirkan di jurusan ini saya tidak dapat bekerja karena kebanyakan orang tidak diterima sebuah perusaliaan karena dalam tittle terdapat Islam di belakangnya.

Dari hasil wawancara di atas, diketahui bahwa daya tarik mahasiswa baru memilih Jurusan Manajemen Pendidikan Islam adalah karena Manajemen Pendidikan Islam telah terakreditasi $\mathrm{B}$, kemudian pada jurusan tersebut akan diajarkan ilmu pengetahuan tentang Manajemen dan pendidikan Islam dan juga karena kriteria yang diinginkan untuk mencapai cita-cita bekerja di bank.

Di samping sebagai tenaga pendidikan, juga dapat bekerja di berbagai perusahaan. Dengan kata lain peluang kerja sangat luas.

Pada pandangan yang lain, seperti yang di kemukakan oleh Abdul Rauf mengatakan bahwa:

Saya memilih jurusan Manajemen Pendidikan Islam karena saya penasaran seperti apa pembelajaran yang ada di dalamnya, karena Manajemen digabungkan dengan Islam dan sejujurnya tidak tau jurusan yang saya ambil dan setelah saya memilih jurusan Manajemen Pendidikan Islam Alhamdulillah saya lulus.

Menurut Sujemanwati

Karena pertama kali saya mendengar dari kata senior kalau jurusan Manajemen Pendidikan Islam sangat bagus karena kita bisa bekerja di manapun, misalnya guru, di kantor dan di bank.

Menurut Nurhikmawati:

Orientasi kerja yang cukup menjanjikan. Bisa menjadi guru, kerja kantoran, kepala sekolah bahkan dosen, walaupun pilihan Manajemen Pendidikan Islam 
adalah pilihan kedua saya, namun taka da sedikit pun penyesalan telah memilih dan Iulus di UIN dengan jurusan Manajemen Pendidikan Islam.

Senada juga yang disampaikan Riskayanti bahwa:

Ruang kerja yang dimiliki luas bisa bekerja di dunia pendidikan seperti menjadi seorang guru atau bisa bekerja di dunia bisnis dan wirausaha inilah daya Tarik yang dimiliki Manajemen Pendidikan Islam.

Informasi-informasi dari wawancara di atas, menggambarkan bahwa jurusan manajemen pendidikan Islam berorientasi pada lapangan kerja yang luas, baik menjadi pendidik atau di bidang perbankan, serta dapat membuka usaha. Selanjutnya peneliti mewawancarai Satriani, mengatakan bahwa:

Daya Tarik Manajemen Pendidikan Islam yaitu kata Manajemennya karena kata Manajemennya itu saya tertarik mengambil jurusan Manajemen Pendidikan Islam, lagi pula dulu ketika saya mendatar di UNM dan UNHAS saya mengambil jurusan Manajemen tetapi tidak lulus, Makanya saya mengambil Manajemen Pendidikan Islam di UIN dengan harapan Iulus Amin.

Muh. Lutfi Al-qadri mengatakan:

Di jurusan Manajemen pendidikan Islam (MPI) mempunyai daya tarik yang besar karena dijurusan ini kita terfokus pada pendidikan, akan tetapi jurusan selain bisa jadi guru atau kepala sekolah, bisa kerja juga di perkantoran, jadi saya masuk di junisan ini bukan terpaksa tapi kemauan sendiri.

Menurut Azhar akbar:

Daya tarik untuk jurusan Manajemen Pendidikan Islam pada saya yaitu untuk pedoman bagi saya, dengan memilih jurusan ini saya sangat dikabari pada senior-senior saya, bahwa jurusan Manajemen Pendidikan Islam di fakultas tarbiyah dan keguruan sangat popular di fakultas tersebut di bandingkan dengan jurusan yang lain-lain. Lama kelamaan saya memilih jurusan Manajemen Pendidikan Islam itu saya sangat berbahagia karena jurusan Manajemen Pendidikan Islam tersebut banyak peluang untuk seterusnya.

Menurut Musdalifah:

Daya Tarik saya masuk Manajemen Pendidikan Islam yaitu Manajemen Pendidikan Islam daya peluang kerjanya cukup meyakinkan dan Manajemen Pendidikan Islam juga jurusan yang sangat unik, menurut saya keunggulan Manajemen Pendidikan Islam yang saya tahu Manajemen Pendidikan Islam adalah kepala dari semua jurusan dari fakultas tabiyah.

Menurut Safar Karma, mengatakan bahwa:

Alasan saya memilih jurusan Manajemen Pendidikan Islam karena saya belajar dan in gin mengetahui lebih dalam Manajemen Pendidikan Islam agar saya dapat memenej pendidikan yang di daerah-daerah terpencil. 
Dari hasil wawancara di atas, diketahui bahwa jurusan MPI di samping memiliki orientasi kerja yang luas juga karena memiliki kata manajemen. Dalam hal ini mahasiswa ingin mengetahui tentang manajemen itu sendiri. Menurut Faecatul Hikmah:

Mengatakan bahwa menurutnya sebenarnya saya tidak terlalu berminat dengan jurusan ini cuman waktu mendaftar saya lansung mencontreng jurusan ini dan waktu melihat pengumuman saya lulus waktu mau pendaftaran ulang sebenarnya saya tidak mau cuman saya di suru sama sepupu saya, karena kenapa kita membuang waktu untuk mendaftar ulang padahal sudah lulus.

Senada yang diungkapkan oleh Ifa Fadillah, mengatakan bahwa:

Pada awalnya saya tidak tau sama sekali tentang Manajemen Pendidikan Islam, Manajemen Pendidikan Islam merupakan pilihan ke-3 saya, sehingga saya lulus di jurusan ini. Tapi setelah mendapat sedikit informasi tentang Manajemen Pendidikan Islam baru saya mulai tertarik terhadap jurusan tersebut karena mengarah pada pendidikan, karena cita-cita saya memang menjadi seorang pendidik.

Menurut Wardiman Ariyadi mengatakan bahwa:

Sebenarnya saya salah masuk jurusan, tetapi lama kelamaan saya merasa betah di jurusan ini dan peluang kerjanya juga banyak.

Menurut Syamsinar mengatakan bahwa:

Karena awalnya saya didaftarkan oleh teman saya dan teman saya yang memilihkan saya jurusan Manajemen Pendidikan Islam, dengan alasan jurusan Manajemen Pendidikan Islam adalah jurusan yang peluang kerjanya nyata dan luas serta jurusan Manajemen Pendidikan Islam, dilengkapi dengan mata kuliah yang bukan hanya untuk pekerjaan tetapi juga untuk akhlak yang membawa kita menjadi orang yang bermanfaat untuk dunia akhirat.

Lisa Ariyanti mengatakan:

Alasan saya memilih Manajemen Pendidikan Islam atau tertarik ingin masuk di Manajemen Pendidikan Islam bukan sepenuhnya pilihan tepat saya, karena pada awalnya saya Cuma ingin masuk di Manajemen nya saja, tapi pada akhirnya saya lulus di pendidikannya, Namun pilihan itu bukan berarti membuat saya terpaksa mengambil jurusan ini, karena menurut saya Manajemen Pendidikan Islam bukan saja mengajarkan kita untuk memanej tapi juga mengajarkan tentang pendidikan agama Islam.

Juga Jumliana mengatakan:

Sebenarnya tidak ada yang terbenak dalam pikiran saya bahwasanya saya akan masuk di Manajemen Pendidikan Islam. Sebenarnya saya hanya dipilihkan oleh sepupu saya. 
Hal yang sama diungkapkan oleh Nurdianti, mengatakan bahwa:

Daya Tarik saya kepada Manajemen Pendidikan Islam sebenarnya tidak sepenuhnya dari hati karena yang memilih jurusan Manajemen Pendidikan Islam itu bukan saya tapi sepupu saya, dan setelah saya sudah di dalam jurusan itu saya sangat bangga menjadi anak Manajemen Pendidikan Islam karena mata kuliahnya yang aku sukai serta peluang pekerjaannya banyak.

Menurut Firda Rahmayanti:

Karena saya dipengaruhi oleh teman saya sehingga saya memilih Manajemen Pendidikan Islam.

Menurut llham mengatakan bahwa:

Saya memilih jurusan Manajemen Pendidikan Islam karena say tidak lulus di jurusan tehnik jadi saya terpksa memilih Manajemen pendidikan Islam tapi saya bangga karena say bisa kuliah.

Menurut Ratnawati:

Sebenarnya saya tidak tahu apa itu jurusan Manajemen Pendidikan Islam, karena pengaruh jaringan yang tidak baik, sehingga yang tercetak dikartu peserta saya adalah Manajemen Pendidikan Islam, sedangkan jurusan yang saya inginkan adalah Pendidikan Agama Islam.

Menurut Yuna Novriawan Alman mengatakan:

Sebenarnya pertama saya masuk di jurusan ini saya merasa tidak suka atau tidak cocok untuk jurusan ini karena saya berfikir bahwa pekerjaan yang kita dapatkan setelah lulus dari jurusan ini sangat sempi dan tidak sesuai dengan apa yang saya cita- citakan tentara. saya kira saya masuk di FEBI tetapi setelah di jelaskan oleh gum atau dosen dasar - dasar Manajemen pendidikan bahwa kita setelah lulus di jurusan ini hanya bekerja di lembaga pendidikan.

Menurut Nurafika mengatakan bahwa:

Saya sebenarnya memilih teknik informatika, tetapi tidak diterima, malahan saya diterima di jurusan Manajemen Pendidikan Islam, awalnya saya tidak ingin jurusan Manajemen Pendidikan Islam karena saya hanya asal pilih, tetapi setelah saya bertanya kepada kerabat dan senior-senior ternyata jurusan Manajemen Pendidikan Islam banyak peluang kerjanya, setidaknya saya belajar Manajemen dengan berbasis Islam.

Menurut Nurlina, mengatakan:

Jujur saja sebenarnya bukan saya yang memilih jurusan Manajemen Pendidikan Islam ini saya hanya didaftarkan oleh teman aku di jalur SMPTN dan Alhamdulillah saya lulus dan setelah itu saya bertanya- tanya dengan keluarga di rumah dan kakak- kakak senior tentang jurusan Manajemen Pendidikan Islam ini dia bilang jurusan ini baik dan banyak peluang pekerjaan terutama sebagai calon guru insya Allah, jadi saya tetap bertahan apa lagi 
mata kuliahnya banyak berhubungan dengan Islami.

Menurut Nabila Alim Lopa Mengatakan:

Karena saya hanya memilih jurusan awalnya saya tidak tau tentang jurusan ini tetapi setelah banyak bertanya apa itu jurusan Manajemen Pendidikan Islam ternyata mempunyai banyak peluang kerja.

Marjan mengatakan:

Sebenarnya saya masuk jurusan Manajemen Pendidikan Islam karena awalnya di seluruh kakak dan dia sudah tau bagaimana Manajemen Pendidikan Islam maka dari itu saya mengambilnya dan Alhamdulillah sampai hari ini jaman dengan jurusan ini.

Dari beberapa hasil wawancara di atas, dapat diketahui bahwa mahasiswa pada awalnya tidak mengenal jurusan MPI, ada yang sekedar mencontreng jurusan ini, ada karena pengaruh-pengaruh keluarga atau kakak senior, didaftarkan oleh temannya, bahkan karena tidak lulus di tempat lain (seakan-akan pelarian). Sekalipun seperti itu, mereka pada akhirnya menyukai jurusan ini.

Faktor Pendorong Mahasiswa Baru untuk memilih Jurusan Manajemen Pendidikan Islam di UIN Alauddin Makassar.

Untuk mengetahui faktor-faktor pendorong Mahasiswa baru dalam memilih jurusan Manjemen Pendidikan Islam tahun akademik 2015/2016, peneliti mewawancarai informan sebagai berikut:

Menurut Nurjanna dan Faecatul Hikmah mengatakan bahwa:

Faktor yang mendorong untuk masuk pada jurusan Manajemen Pendidikan Islam Fakultas Tarbiyah dan Keguruan UIN Alauddin Makassar, yaitu karena keinginan sendiri dan dorongan orang tua, kemudian jurusan Manajemen Pendidikan Islam sudah terakreditasi B.

Selanjutnya Sujemanwati mengatakan bahwa:

Faktor orang tua karena di dalam jurusan Manajemen Pendidikan Islam sangat bagus karena kita bisa belajar mengenai agama selain itu akreditasinya juga bagus.

Muh. Lutfi Al-Qadri mengatakan bahwa:

faktor pendorong saya yaitu orang tua mendukung saya di jurusan ini dan memang juga dari diri sendiri sehingga tidak ragu lagi di jurusan ini.

Senada yang diungkapkan Musdalaipa bahwa:

karena sudah terakreditasi dan merupakan faktor penasaran dan juga dukungan dari orang tua dan saya juga berasal dari jurusan IPS.

Menurut Nurdianti mengatakan bahwa:

Faktor pendorong saya masuk jurusan Manajemen Pendidikan Islam karena 
sepupu saya menawarkan ke jurusan itu dan saya termotivasi oleh kakak-kakak yang di jurusan tapi saya melihat kakak senior saya yang sudah menjadi sarjana dan menggapai cita-citanya dan saya juga senang karena orang tua dan keluarga sangat setuju saya memasuki jurusan Manajemen Pendidikan Islam.

Dari wawancara di atas, diketahui bahwa faktor pendorong mahasiswa memilih masuk jurusan Manajemen Pendidikan Islam adalah karena faktor keinginan sendiri, dukungan keluarga (kakak, orang tua) dan jurusan Manjemen Pendidikan Islam sudah terakreditasi $B$, serta faktor jurusan waktu di SMA/sederajat.

Selanjutnya Ifa Fadillah, Nxirafika dan Firda Rahmayanti mengatakan bahwa: Faktor sehingga masuk Manajemen Pendidikan Islam adalah keluarga saya dan faktor lapangan pekerjaan, karena Manjemen pendidikan Islam memiliki peluang kerja yang luas, sehingga memilih jurusan Manajemen Pendidikan Islam.

Marjan mengatakan bahwa:

Pendorong saya masuk di jurusan ini karena kakak saya meyakinkan bahwa jurusan ini baik dan bisa kerja di kantor dan di sekolah.

Menurut Nurhidayah bahwa:

Faktor orang tua saya yang memberi dukungan lebih, faktor lapangan pekerjaan karena Manajemen Pendidikan Islam memiliki peluang kerja yang luas, faktor keinginan karena dari dulu saya ingin menjadi seorang menejer.

Armin mengatakan bahwa:

Faktor pendorong sehingga saya memilih Manajemen pendidikan Islam adalah faktor lapangan kerja, karena kebetulan di kabupaten majene' adalah kota pendidikan itulah mengapa saya memilih Manajemen pendidikan Islam.

Menurut Jumliana bahwa:

Faktor yang menjadi pendorong memilih Manajemen Pendidikan Islam karena lapangan kerjanya luas misalnya, menjadi kepala sekolah, guru, wirausaha, menjadi pegawai bank dan masih banyak lapangan kerja lainnya.

Menurut Nurlina bahwa:

Faktor pendorong aku, keluarga di kampong, kemauan sendiri, teman-teman, karena saya yakin dengan jurusan Manajemen Pendidikan Islam insya Allah semua cita-cita aku bisa tercapai dan aku akan tetap bekerja keras dan akan belajar bersungguh-sungguh.

Dari hasil wawancara di atas, diketahui bahwa faktor pendorong mahasiswa memilih jurusan Manajemen Pendidikan Islam di samping dukungan orang tua juga karena faktor lapangan kerja. Peluang kerja bagi alumni manajemen pendidikan Islam terbentang luas, baik menjadi pendidik maupun pekerjaan-pekerjaan perkantoran.

Selanjutnya Riskayanti mengatakan bahwa : dorongan dari guru, dorongan dari 
kakak, karena kampusnya Negeri dan jurusan yang saya pilih terakreditasi.

Ince Rika Rahim mengatakan bahwa:

Saya termotivasi oleh diri sendiri berada di jurusan ini, walaupun orang berkata bahwa jurusan ini, walaupun orang berkata bahwa jurusan ini tidak diminati oleh banyak orang karena lapangan kerjanya tidak banyak diterima, tetapi jika ada kemauan pasti ada jalan di jurusan ini.

Satriani mengatakan bahwa:

Yang mendorong saya mengambil Manajemen Pendidikan Islam yaitu inisiatif diri sendiri, karena menurut saya kampusnya sudah negeri, jurusannya juga membuat saya tertarik.

Dari wawancara di atas, diketahui bahwa faktor pendorong mahasiswa memilih jurusan Manajemen Pendidikan Islam adalah faktor motivasi dan inisiatif sendiri serta UIN Alauddin Makassar berstatus Negeri.

Selanjutnya Syamsinar mengatakan bahwa:

faktor pendorong saya masuk MPI adalah faktor ekonomi karena SPP pada jurusan

Manajemen Pendidikan Islam tidak terlalu tinggi, faktor pekerjaan, faktor orang tua, faktor kelulusan.

Wawancara tersebut di atas, diketahui bahwa salah satu faktor pendorong memilih jurusan Manjemen Pendidikan Islam karena faktor ekonomi.

Lisa Ariyanti mengatakan bahwa:

Faktor yang mendorong saya untuk memilih Manajemen Pendidikan Islam, Karena di dalam Manajemen Pendidikan Islam, kita bukan Cuma belajar mendalami ilmu agama agar dapat mengatur pendidikan agama Islam kedepannya lebih baik lagi.

Dari informasi dia atas, dapat dipahami bahwa mahasiswa memilih jurusan Manajemen Pendidikan Islam adalah karena faktor untuk mendalami ilmu agama. Selanjutnya menurut Nur Hatika bahwa:

Faktor masuk Manajemen Pendidikan Islam karena aku memilih Manajemen umum tapi Iulusnya di Manajemen Pendidikan Islam dan Manajemen Pendidikan Islam termasuk juga Manajemen.

Dari informasi ini menggambarkan bahwa faktor pendorong memilih jurusan Manajemen Pendidikan Islam karena Iulus pada jurusan tersebut.

\section{KESIMPULAN}

Daya tarik mahasiswa baru memilih jurusan Manajemen Pendidikan Islam adalah karena Manajemen Pendidikan Islam sudah terakreditasi dan MPI mempunyai lapangan kerja yang luas. Kemudian pada jurusan Manajemen Pendidikan Islam ada keseimbangan pembelajaran agama dan umum.

Alasan mahasiswa barn untuk memilih jurusan Manajemen Pendidikan Islam 
adalah karena keinginan mereka untuk bekerja di perkantoran atau orientasi kerja. Kemudian karena ingin mengetahui dan memperdalam ilmu-ilmu manajemen dan pendidikan, serta memperdalam pengetahuan agama Islam. Di sisi lain ada yang memilih karena keterpaksaan, karena tidak lulus di jurusan lain, sebab harapan mereka lulus pada jurusan yang diinginkan, bukan pada jurusan MPI. Akan tetapi pada akhirnya mereka menyenanginya jurusan tersebut.

Harapan yang mahasiswa inginkan pada jurusan Manajemen Pendidikan Islam adalah setelah selesai kuliah mereka dapat menjadi orang sukses dan membahagiakan orang tuanya. Sukses dalam segala hal, baik sebagai pegawai, pemimpin yang bertanggung jawab atau dalam bewirausaha. Termasuk menjadi tenaga pendidik (guru, dosen) yang profesional, sehingga dapat mencerdaskan anak-anak bangsa, bahkan sampai kepada pembangunan sekolah-sekolah. Kemudian mampu memperbaiki dan mengembangkan sistem manjemen pendidikan

Faktor-faktor pendorong mahasiswa memilih masuk jurusan Manajemen Pendidikan Islam adalah karena faktor keinginan sendiri, dukungan keluarga (kakak, orang tua) dan jurusan Manjemen Pendidikan Islam sudah terakreditasi B, serta faktor jurusan waktu di SMA/sederajat. Dari hasil wawancara di atas, diketahui bahwa faktor pendorong mahasiswa memilih jurusan Manajemen Pendidikan Islam di samping dukungan orang tua juga karena faktor lapangan kerja. Peluang kerja bagi alumni manajemen pendidikan Islam terbentang luas, baik menjadi pendidik maupun pekerjaan-pekerjaan perkantoran. Kepada seluruh yang terkait dengan jurusan Manajemen Pendidikan Islam agar selalu berusaha untuk mengembangkan jurusan dengan program-program dan ide-ide yang cemerlang, sehingga Manajemen Pendidikan Islam dapat dan mampu bersaing dengan jurusan-jurusan lain. Untuk mahasiswa Manajemen Pendidikan Islam belajarlah secara tekun dan bersungguh-sungguh, sehingga kelak kalian menjadi sarjana yang berkualitas yang bermanfaat bagi keluarga, agama, bangsa dan Negara.

\section{DAFTAR PUSTAKA}

Abuddin Nata, Manajemen Pendidikan Mengatasi Kelemahan Pendidikan di Indonesia, Jakarta: Kencana Predana Media Group, 2003.

Baego Ishak dan Suarga, Dasar - Dasar Manajemen Pendidikan, Makassar: CV. Berkah Utami, 2009.

Cahaya Khaeroni, Pengawasan dalam Pendidikan, cahavakhaeroni. blogspot.com/2012/01/pengawasan-dalam-pendidikan.

Departemen Pendidikan dan Kebudayaan RI, Undang-Undang Nomor 20 Tahun 2003 Tentang Sistem Pendidikan Nasional Beserta Penjelasannya, Jakarta: 
Pustaka, 2003.

Djaali, Psikologi Pendidikan, Jakarta: Bumi Aksara, 2007.

Forum Sejawat, Manajemen Pendidikan, 1 Februari 2011, http://forumsejawat Wordpress.com /2011/02/01 / pengertian-manajemen-pendidikan/

H.A.R. Tilaar, Manajemen Pendidikan Nasional Kajian Pendidikan Masa Depan, Cet. Ke-7; Bandung: PT. Remaja Rosda Karya, 2004.

Hamzah Yakub, Menuju Keberhasilan Manajemen dan Kepemimpinan, Cet. Ke-1; Bandung: CV. Diponegoro, 1994.

Husaini Usman, Manajemen-Teori, Praktik, dan Riset Pendidikan, Jakarta: PT. Bumi Aksara.

Mudyahardjo, Redja. 2013. Pengantar Pendidikan Sebuah Studi awal Tentang Dasar-Dasar Pendidikan pada Umumnya dan Pendidikan Indonesia. Jakarta: Rajagrafmdo Persada

Mustari Muahammad. Manajemen Pendidikan. Jakarta: Raja Grafindo Persada, 2014

Sobry Sutikno, Manajemen Pendidikan-Langkah Praktis Mewujudkan Lembaga Pendidikan Yang Unggul, Get Ke-1; Lombok: Holistica, 2012.

Sutrisno Hadi, Metodologi Penelitian, Yogyakarta: Pustaka Pelajar, 1986.

Tim Dosen Administrasi Pendidikan Universitas Pendidikan Indonesia, Manajemen Pendidikan, Get. Ke-3; Bandung: Alfabeta, 2010.

Tohirin, Psikologi Pembelajaran PA1, Jakarta: Raja Grafindo Persada, 2005. 